\title{
Population dynamics, infestation and host selection of Vexilla vexillum, an ectoparasitic muricid of echinoids, in Madagascar
}

\author{
Devarajen Vaïtilingon $^{1,3, *}$, Igor Eeckhaut ${ }^{2,3}$, Didier Fourgon ${ }^{1,3}$, Michel Jangoux ${ }^{1,2,3}$ \\ ${ }^{1}$ Laboratoire de Biologie Marine, CP 160/15, Université Libre de Bruxelles, Avenue F. D. Roosevelt 50, 1050 Bruxelles, Belgium \\ ${ }^{2}$ Laboratoire de Biologie Marine, Université de Mons-Hainaut, 7000 Mons, Belgium \\ ${ }^{3}$ Aqua-lab, Institut Halieutique et des Sciences Marines, Université de Tuléar, BP 141, 601 Tuléar, Madagascar
}

\begin{abstract}
The symbiotic interaction, population and infestation dynamics of the muricid Vexilla vexillum (Gmelin, 1791) on 2 echinoid species, Tripneustes gratilla (Linnaeus, 1785) and Echinometra mathaei (Blainville, 1825), was investigated on the barrier reef off Toliara (Madagascar). $V$. vexillum is an ectoparasitic muricid which was exclusively found in association with sea urchins, on which it moves freely and browses over the integument. Host recovery from damage caused by muricid grazing was dependent on lesion size. Small lesions regenerated while larger ones were subjected to secondary infections, which led to host death. A 27 mo survey (2000 to 2003) of the muricid's population dynamics revealed annual recruitment episodes during the mid-summer season (December to January). Patterns of recruitment peaks were apparently linked to its reproductive cycle. Demographic parameters including growth and mortality rates of the muricid were estimated from analysis of sizefrequency distributions. Growth was described by the von Bertalanffy function. The model predicts that $V$. vexillum is a fast-growing species in which asymptotic shell length $\left(L_{\infty}=1.024 \mathrm{~cm}\right)$ is reached 6 to 7 mo after recruitment. The growth rate constant $K$, and shell length at settlement $L_{0}$, were estimated from the model. Estimated mortality rate was $55 \% \mathrm{yr}^{-1} ; V$. vexillum has a short lifespan. The observed high growth rate together with the high mortality rate suggest that $V$. vexillum is a semelparous species. A field survey of the infestation dynamics of $V$. vexillum was performed during 3 consecutive years, with seasonal variation in parasite prevalence on both echinoid host species. Although both T. gratilla and E. mathaei were infested, a preference towards T. gratilla was noted. This was attributed to $T$. gratilla's test morphology (which allows better accessibility for grazing), to the muricid's higher recognition capacity of $T$. gratilla (as determined by olfactory experiments) and to the high recruitment predictability of that particular host. This study provides novel information on the biology of $V$. vexillum, an echinoid epidermal grazer, and its relationship with 2 ecologically and economically important echinoid species.
\end{abstract}

KEY WORDS: Echinoidea $\cdot$ Host recognition $\cdot$ Infestation $\cdot$ Parasitism $\cdot$ Population dynamics

\section{INTRODUCTION}

Echinoderms are hosts to a wide variety of symbionts from most marine phyla, gastropods being among the major ones (see Barel \& Kramers 1977 and Jangoux 1990 for reviews). Most parasitic gastropods of echinoderms belong to the superfamily Eulimoidea (Meso- gastropoda, Prosobranchia: Vaught 1989) which comprises either ecto- or endoparasites (see Warén 1983 and Jangoux 1990 for reviews). Endoparasitic eulimids mostly occur in asteroids and holothuroids, within the coelomic cavity of their hosts. These species are completely adapted to their endoparasitic mode of life; the adults do not resemble gastropods (Jangoux 1990). 
Among ectoparasitic eulimids, varying degrees of specialisation occur. More specialised ectoparasite species are permanently attached to their hosts, and feed on the dermal tissues and body fluids of their hosts through their proboscis (Lützen 1972, 1976, Warén 1980). Less-specialised ectoparasites are not permanently attached to their hosts, on which they move freely while browsing over the epidermis (Ponder \& Gooding 1978, Fujioka 1985). While most epidermal grazers on echinoids are eulimids, muricid species are also involved in such associations although little is known about the exact host-parasite relationship. Kay (1979) described 2 muricid species, Vexilla lineata and $V$. vexillum, as echinoid epidermal grazers. $V$. vexillum appears to be the most common of these, being distributed along rocky shores throughout the Indo-West Pacific (Kay 1979).

Muricids, like most neogastropods, have a wide range of specialised predatory characteristics and feed on barnacles and other gastropods (Hughes 1986). Furthermore, some have developed a parasitic association with other molluscs such as bivalves (Warén 1983). Vexilla vexillum is a rare example of a muricid associated with echinoids. In Hawaii, it has always been found associated with, and feeding on echinoids such as Echinometra spp. and Colobocentrotus spp. (Kay 1979). In contrast to most eulimid-echinoderm relationships, the $V$. vexillum-echinoids association has received little attention. Recent surveys of the southwest coast of Madagascar (off Toliara) revealed the occurrence of the muricid species on 2 echinoids, Tripneustes gratilla and Echinometra mathaei. Its association with these 2 echinoids is important because these echinoid species are both ecologically and economically important. T. gratilla and E. mathaei have major roles in benthic community structure; the former is a primary herbivore and the latter is a major reef-eroder (Lawrence 1975). They are edible species and are exploited for their gonads (Lawrence \& Agatsuma 2001, McClanahan \& Muthiga 2001).

The exact relationship between the muricid Vexilla vexillum and its echinoid hosts is not known. The aim of the present study was to elucidate the biology of $V$. vexillum, with particular emphasis on its population structure, infestation dynamics, host-recognition mechanism and its potential effect on its hosts.

\section{MATERIALS AND METHODS}

Sampling site. This study was performed on the barrier reef off Toliara, on the south-west coast of Madagascar (Fig. 1). The study site, Ambatobe (23 25' $00 \mathrm{~S}$, $43^{\circ} 39^{\prime} 23 \mathrm{E}$ ), was located on the boulder tract of the seaward slope of the reef flat. This zone is charac-

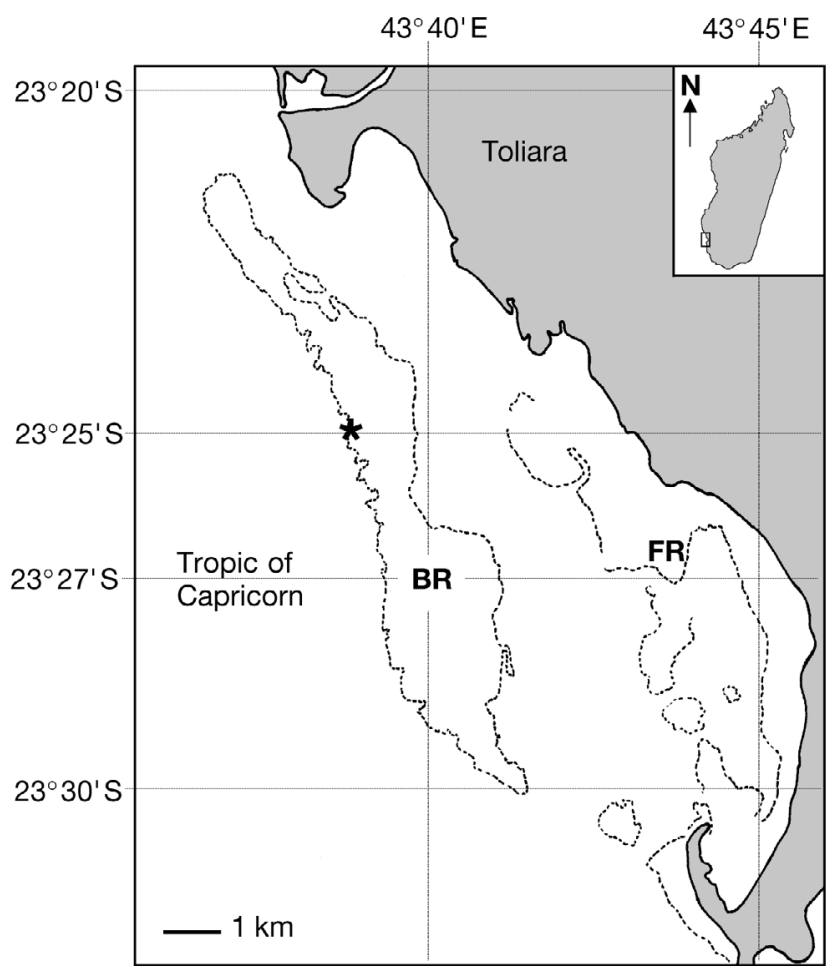

Fig. 1. Coastal region of Toliara, Madagascar, showing location of sampling site, Ambatobe ${\left({ }^{*}\right)}^{*}$ on barrier reef (BR). FR: fringing reef

terised by blocks of limestone on which different algal and coral species grow (Régis \& Thomassin 1982, UNEP/IUCN 1988). Dense populations of both echinoid hosts, Tripneustes gratilla (Linnaeus, 1758) and Echinometra mathaei (Blainville, 1825) together with Vexilla vexillum (Gmelin, 1791) are found in these habitats.

Ecological surveys. Sampling procedure: The association between Vexilla vexillum and Tripneustres gratilla was followed from February 2000 to January 2003 and that between $V$. vexillum and Echinometra mathaei from November 2001 to January 2003. During these periods, the population structures of the hosts and parasite were determined at low tides using the quadrat method. Each month, 5 to 10 randomly placed $1 \mathrm{~m}^{2}$ quadrats were sampled in the population of E. mathaei, and 20 to 46 quadrats were sampled in the T. gratilla population. However, in May 2000 our sampling time was limited by bad weather conditions and only 11 quadrats were analysed. For both host species, the number of infested and non-infested individuals were counted in each quadrat. Each echinoid was measured (ambitus diameters and height) to the nearest $1 \mathrm{~mm}$ with calipers; for every infested echinoid, the number and position of $V$. vexillum were also noted. Surface sea water temperature was also recorded each month using a thermometer (WTW LF 330, Bioblock Scientific). Size measurements (shell length to the 
nearest $0.01 \mathrm{~mm}$ ) of each muricid found on T. gratilla were recorded from November 2000 onwards, those on E. mathaei from November 2001 onwards.

Infestation study: Variations in infestation of echinoid hosts by Vexilla vexillum were investigated by quantifying its prevalence and intensity (terminology according to Bush et al. 1997) at monthly intervals during the study periods. The prevalence of the muricid was evaluated for both host species as:

$$
P=\left(n_{\mathrm{ie}} / n_{\mathrm{e}}\right) \times 100
$$

where $P$ is prevalence in percent, $n_{\mathrm{ie}}$ is number of infested echinoid hosts and $n_{\mathrm{e}}$ is total number of echinoid hosts sampled.

The intensity of infestation was expressed by 2 indices: (1) $I$ (intensity), determined for both echinoid hosts, represents the number (min/max) of Vexilla vexillum observed on infested echinoids at each sampling date and (2) $I_{\mathrm{ms}}$ (mean intensity), determined for Tripneustes gratilla only, represents the mean number of $V$. vexillum observed per unit surface area of infested echinoids. Calculations of the surface area of T. gratilla's test were based on the assumption that its shape is a section of a sphere parallel to the equatorial plane. This assumption was derived from the work of Ellers \& Telford (1992) and Ellers (1993), who suggested that the shape of a regular echinoid test is similar to a water-filled balloon resting on a table. Using this criterion, the surface area of $T$. gratilla's test was estimated as:

$$
S A=2 \pi r h+\pi r^{2}
$$

where $S A$ is surface area in $\mathrm{cm}^{2}, r$ is radius (half the test diameter) in $\mathrm{cm}$ and $h$ is test height in $\mathrm{cm}$. For each infested echinoid, the number of $V$. vexillum per unit surface area was calculated and $I_{\mathrm{ms}}$ expressed as the mean value.

The relationship between infestation (prevalence and intensity) and host density was studied. The density of each echinoid species was calculated as the number of individuals per $1 \mathrm{~m}^{2}$ quadrat and expressed as the monthly mean value.

Population structure of Vexilla vexillum: The population structure study of $V$. vexillum was aimed at determining the recruitment periods, monitoring changes in density over time, and estimating annual growth and mortality rates. Data used in this study were all recorded from Tripneustes gratilla.

Determination of recruitment events was done after generating monthly size-frequency (length-frequency) distributions from November 2000 to January 2003 by pooling individuals in size classes of $0.1 \mathrm{~cm}$. These distributions were analysed only when sufficient gastropods were sampled ( $\mathrm{n}>35$ ). Length-frequency data were first tested against a normal distribution (Kolmogorov-Smirnov test); any deviation from normality would indicate either skewed, lepto- or platy-kurtic distributions or possible multimodality. When multimodality was suspected, separation of the observed polymodal length-frequency distributions into component normal distributions (subgroups) was achieved by C.A.MAN programme (Böhning et al. 1992: freely downloadable from www.medizin.fu-berlin.de/sozmed/ caman.html). This programme estimates finite mixtures of distributions using the maximum-likelihood method. Information such as the number of population subgroups, their mean values and relative sizes expressed as weights were extracted from the length-frequency data. The information generated by C.A.MAN was used as initial values in the MIX programme (Macdonald \& Pitcher 1979) to check their significance using a chi-square test.

The density of Vexilla vexillum on Tripneustes gratilla was studied at monthly intervals (from February 2000 to January 2003) and expressed as the number of gastropod individuals per unit host-surface area. The surface area of $T$. gratilla was determined as above (see last subsection) and the density was calculated as:

$$
D=n_{\mathrm{p}} / S
$$

where $D$ is density expressed as number of gastropod individuals per unit host surface area $\left(\mathrm{m}^{2}\right), n_{\mathrm{p}}$ is the total number of $V$. vexillum sampled and $S$ is the total surface area of T. gratilla sampled (infested and noninfested) in $\mathrm{m}^{2}$.

Growth parameters were estimated from cohort analysis after identification of new recruits. Means of new recruit cohorts were followed over time and growth was described using the von Bertalanffy growth function (see Ebert 1999):

$$
L_{t}=L_{\infty}\left[1-b\left(\mathrm{e}^{-K(t)}\right)\right]
$$

where $L_{t}$ is shell length at Time $t, t$ is time after settlement, $L_{\infty}$ is asymptotic shell length, $K$ is growth rate constant with units of time (in years), and $b$ (scaling parameter) is determined by length at settlement $L_{0}$ (when $t=0$ ):

$$
b=\left(L_{\infty}-L_{0}\right) / L_{\infty}
$$

The annual mortality rate $(q)$ in a population of Vexilla vexillum was calculated as follows (Ebert 1999):

$$
q=1-\mathrm{e}^{-Z}
$$

where $Z$ is the instantaneous mortality coefficient $\mathrm{yr}^{-1}$. The value of $Z$ was estimated from the lengthfrequency distributions using the programme Zkan (Ebert 1973, 1999). This programme is applicable when recruitment is periodic, and uses the average size of individuals in a population at Time $T$ (time following recruitment) to determine the mortality parameter. The mean shell length of each length-frequency 
distribution is calculated together with the respective $T$ values (yr). The time at recruitment $(T=0)$ is considered as the time when mean observed shell length is lowest. Given these data, together with $L_{\mathrm{R}}$ (shell length at recruitment), sp (shape parameter) (see Ebert 1999), and $K$ and $L_{\infty}$ (determined from Eq. 4), the programme is designed to estimate the mortality parameter $Z$. The method used by the Zkan programme is a nonlinear regression, and therefore the best estimate of parameter $Z$ is obtained when the residual sum-of-squares (RSS) is at its lowest.

Relationship between Vexilla vexillum and its hosts. The relationship between host diameter and muricid shell length was calculated for both host species using pooled data from the corresponding periods of survey. For Tripneustes gratilla, an additional relationship was examined between the number of gastropods found on an individual and its corresponding diameter. To determine if recruitment events of the gastropod and hosts coincided, we evaluated and compared the monthly percentage of small individuals (which could be assimilated as new recruits) of both pairs. New recruits of $T$. gratilla (mean $\pm \mathrm{SD}$ adult test diameter $=5.7 \pm 1.1 \mathrm{~cm}$ ) were considered to be $<3 \mathrm{~cm}$ in diameter, while Echinometra mathaei recruits (mean \pm SD adult test diameter $=3.7 \pm 0.6 \mathrm{~cm}$ ) were considered to be $<2 \mathrm{~cm}$. The percentage of new recruits of $V$. vexillum was determined from the length-frequency distributions.

Biological interactions between Vexilla vexillum and Tripneustes gratilla. The interaction between $V$. vexillum and T. gratilla was observed in the laboratory during infestation experiments. Individuals of $V$. vexillum, together with non-infested T. gratilla were collected from the reef, brought to the laboratory and left in separate aquaria with running sea water (for aquarium system, see 'toboggan structures' in Grosjean et al. 1998 and Jangoux et al. 2001), and 3 d later, a batch of 20 host individuals (mean \pm SD test diameter $=4.6 \pm 0.5 \mathrm{~cm}$ ) and 20 muricids (mean $\pm \mathrm{SD}$ shell length $=1.11 \pm 0.20 \mathrm{~cm}$ ) were isolated. Each host individual was put in contact with 1 muricid and the parasitehost pair was placed in a sieve-tube (cylindrical plastic tube of $20 \mathrm{~cm}$ long and $10 \mathrm{~cm}$ in diameter, closed at both ends by $1 \mathrm{~mm}$ mesh sieves). Each of the 20 sievetubes was marked individually and left in the aquaria with running sea water. The infestation dynamics of $T$. gratilla were evaluated by counting the number of infested individuals 2, 4, 6, 10 and $14 \mathrm{~d}$ after initial contact between parasite and host individuals. For each infested host, the position of the muricid on the test was recorded. In additional to the classical division into ambulacral and interambulacral zones of a regular echinoid test, T. gratilla's test can also be subdivided into 10 bare zones interspersed by 10 spiny zones (Mortensen 1943). The bare zones are located in the median areas of the ambulacral and interambulacral regions. The position of the muricid relative to the bare and spiny zones was noted.

Using experimentally infested Tripneustes gratilla individuals (same infestation protocol as above), characteristics of the host test-lesions (parts of the echinoid test grazed) recorded after the first sign of grazing by the muricid were followed individually over time. At the first sign of grazing, the gastropod was removed and the size of the lesion measured and photographed. The echinoid was then replaced alone in the sieve-tube and fed regularly. The same lesions were measured and photographed again 14 d later. Host echinoids whose lesions did not seem to increase in size were dissected and pieces of the test with lesions were fixed for scanning electron microscopy (SEM). They were fixed at room temperature in Bouin's fluid (without acetic acid) for $12 \mathrm{~h}$ and then dehydrated in a graded series of ethanol concentrations. Dehydrated test samples were dried by the critical-point method, mounted on aluminium stubs, coated with gold and observed with a Jeol JSM-6100 SEM. The remaining infested hosts were left in the sieve-tubes and examined 21 d later (35 d after first grazing signs); 10 individuals of Vexilla vexillum were also dissected and their radula were removed and treated as above for observation under SEM.

Host-recognition and specificity. The role of olfaction in the recognition of echinoid hosts by Vexilla vexillum was determined by a series of olfactory tests using Davenport's Y-tube system (Davenport 1950, VandenSpiegel et al. 1998, Eeckhaut et al. 2001). This system allows any aquatic organism (here the gastropod) to choose between 2 chemical stimuli carried by a water flow. We used 3 opaque plastic aquaria (A, B and $\mathrm{C})$ of the same dimensions $(15 \times 15 \times 8 \mathrm{~cm})$; these were connected to each other by a Y-shaped glass tube (internal diameter $=1.3 \mathrm{~cm}$, branch length $=$ $7.3 \mathrm{~cm}$ ) (Fig. 2). A laminar water current, regulated at $120 \mathrm{ml} \mathrm{min}^{-1}$, flowed from Aquaria A and B to C, passing through the Y-tube. A tap in Aquarium $\mathrm{C}$ allowed drainage of water and flow regulation. The muricid was placed at one end of the single Y-tube branch connected to Aquarium $\mathrm{C}$, and presented with 2 chemical stimuli,1 each in Aquaria A and B, which were both connected to one of the paired branches of the Y-tube. Since a water current is laminar, this system allows chemical stimuli $\mathrm{A}$ and $\mathrm{B}$ to flow into the single Y-tube branch without being mixed; stimulus A remained in the left half and stimulus $B$ in the right half of the tube. If a muricid responds to a stimulus ('stimulated individual'), it will move into the Y-tube until it reaches the intersection of the paired branches and then turn either to the left (Aquarium A) or to the right (Aquarium $\mathrm{B}$ ), depending on the origin of the stimulus. 
Fig. 2. Davenport's Y-tube system used in testing role of olfaction in host-recognition by Vexilla vexillum. Dashed lines on paired branches: choice-line limit; arrows indicate direction of water flow

We conducted 5 tests of 30 replicates each (150 individuals), using either filtered sea water (FSW) and/or echinoid species as stimuli. We tested 3 echinoid species, the 2 host species (Tripneustes gratilla and Echinometra mathaei) and Stomopneustes variolaris, a cooccurring echinoid species which is never infested by Vexilla vexillum. Echinoid individuals tested were all uninfested. Since tested echinoids were of different sizes, precautions were taken to ensure that their wet weights ranged within 250 to $280 \mathrm{~g}$. Experiments were run with individuals of $V$. vexillum (mean $\pm \mathrm{SD}$ shell length $=1.34 \pm 0.18 \mathrm{~cm}$ ) collected from the reefs and kept isolated in an aquarium for $3 \mathrm{~d}$ before testing. For each test, 2 parameters were noted: (1) the choice between the 2 aquaria $A$ or $B_{\text {; }}$ and (2) the response time, i.e. the time from when the muricid started to move until it reached the choice-line limit (Fig. 2) of one of the paired branches. An assay was considered void if the muricid stayed still for more than $20 \mathrm{~min}$ ('non-stimulated individual'). After each assay, the Ytube system was washed thoroughly with distilled water and rinsed with $1 \mu \mathrm{m}$ FSW. The connections between paired branches were then interchanged by rotating the Y-tube by $180^{\circ}$. The hypothesis that muricids were chemically attracted to their echinoid hosts was investigated by comparing the number of stimulated muricid individuals recorded during exposure to host stimuli with the number of stimulated individuals recorded when the 2 aquaria contained only FSW (control experiment).
Statistical analysis. The non parametric KruskalWallis test (Zar 1996) was used to compare degree of variability of infestation intensity and host density during the study periods. Fitting of the von Bertalanffy growth function (Eq. 4) was done by the nonlinear least-square estimation method using Systat 8.0 (SPSS 1998). To check the fitting of our growth model, the proportion of variance explained by the model, expressed by the $\mathrm{R}^{2}$ statistic, was used together with the significance of the regression determined by an F-test (see Draper \& Smith 1998). Experimental results obtained from olfactory tests were compared using chi-square tests (Siegel \& Castellan 1988). For all tests and estimations, the significance level used was $\mathrm{p} \leq 0.05$.

\section{RESULTS}

\section{Infestation study}

A total of 12304 individuals of Tripneustes gratilla was collected throughout the whole sampling period, among which $944(7.7 \%)$ were infested by Vexilla vexillum (Table 1$)$. Mean $( \pm \mathrm{SD})$ annual prevalence $(P)$ was $6.2 \pm 5.9 \%$ in $2000,7.4 \pm 7.1 \%$ in 2001 and $8.3 \pm$ $6.0 \%$ in 2002 . The high variability observed in annual prevalence was due to the presence of a cycle characterised by sharp peaks in February to March where $P$ values of up to $26.6 \%$ were noted (Fig. 3A). This annual cycle showed a similar pattern in 2000 and 2001 with 1 maximum followed by a sharp decrease to minimum values of $<5 \%$ by April and May. In 2002, the pattern differed slightly, as shown by the shape of the graph (Fig. 3A): peak $P$ was observed in February $(18.8 \%)$, gradually decreasing to values $<1 \%$ by October. This resulted in the highest average annual prevalence observed (mean value of $8.3 \%$ of infested T. gratilla). This was related to the mean $( \pm \mathrm{SE})$ annual density of T. gratilla, which was $7.4 \pm 0.9$ ind. $\mathrm{m}^{-2}$ in 2002 compared to $3.9 \pm 1.7$ ind. $\mathrm{m}^{-2}$ in 2000 and $3.8 \pm$ 0.8 ind. $\mathrm{m}^{-2}$ in 2001 (Fig. 3C). The annual variation in the mean $(+\mathrm{SE})$ intensity of infestation of $T$. gratilla, as expressed by $I_{\mathrm{ms}}$ (Fig. 3B) was less evident due to the high variability of mean values. However, a certain trend was observed throughout the study periods, with significantly (Kruskal-Wallis test, p < 0.05) higher mean values in January-February (0.0170.022 ind. $\mathrm{cm}^{-2}$ of infested T. gratilla). $I_{\mathrm{ms}}$ was at its lowest in November 2000, with a mean value of 0.009 ind. $\mathrm{cm}^{-2}$ of infested T. gratilla. These results were confirmed by values of $I$ (intensity) (Table 1), with individuals of $T$. gratilla bearing up to $8 \mathrm{~V}$. vexillum observed in February 2001. Highest intensity was recorded in January 2002, with 1 host individual infested by 11 parasites. 
Table 1. Tripneustes gratilla (T.g) and Echinometra mathaei (E.m). Monthly sampling parameters. $n_{\mathrm{q}}$ : number of sampled quadrats, $n_{\mathrm{e}}$ : number of sampled echinoids, $n_{\mathrm{ie}}$ : number of infested echinoids, $n_{\mathrm{p}}$ : number of sampled gastropods on echinoids, $I$ : intensity of infestation expressed as number $(\min / \max )$ of $V$. vexillum on infested echinoids. Note: study on E. mathaei began in November 2001

\begin{tabular}{|c|c|c|c|c|c|c|c|c|c|c|}
\hline \multirow{3}{*}{$\begin{array}{l}\text { Date } \\
\mathbf{2 0 0 0}\end{array}$} & \multirow{2}{*}{\multicolumn{2}{|c|}{$\begin{array}{c}n_{\mathrm{q}} \\
\text { T.g E.m }\end{array}$}} & \multirow{2}{*}{\multicolumn{2}{|c|}{$n_{\mathrm{e}}$}} & \multirow{2}{*}{\multicolumn{2}{|c|}{$\begin{array}{c}n_{\mathrm{ie}} \\
\text { T.g E.m }\end{array}$}} & \multirow{2}{*}{\multicolumn{2}{|c|}{$\stackrel{n_{\mathrm{p}}}{\text { T.g E.m }}$}} & \multicolumn{2}{|c|}{$I(\min / \max )$} \\
\hline & & & & & & & & & $T . g$ & E.m \\
\hline & & & & & & & & & & \\
\hline Feb & 20 & & 156 & & 22 & & 31 & & $1 / 3$ & \\
\hline Mar & 20 & & 143 & & 31 & & 40 & & $1 / 3$ & \\
\hline Apr & 20 & & 151 & & 5 & & 8 & & $1 / 3$ & \\
\hline May & 11 & & 32 & & 1 & & 1 & & $1 / 1$ & \\
\hline Jun & 20 & & 156 & & 11 & & 14 & & $1 / 2$ & \\
\hline Jul & 20 & & 168 & & 8 & & 10 & & $1 / 3$ & \\
\hline Aug & 20 & & 161 & & 7 & & 8 & & $1 / 2$ & \\
\hline Sep & 25 & & 165 & & 8 & & 9 & & $1 / 2$ & \\
\hline Oct & 20 & & 185 & & 3 & & 3 & & $1 / 1$ & \\
\hline Nov & 20 & & 172 & & 3 & & 3 & & $1 / 1$ & \\
\hline Dec & 20 & & 193 & & 3 & & 5 & & $1 / 3$ & \\
\hline 2001 & & & & & & & & & & \\
\hline Jan & 42 & & 249 & & 28 & & 39 & & $1 / 3$ & \\
\hline Feb & 41 & & 394 & & 105 & & 203 & & $1 / 8$ & \\
\hline Mar & 25 & & 251 & & 36 & & 52 & & $1 / 5$ & \\
\hline Apr & 42 & & 416 & & 47 & & 66 & & $1 / 3$ & \\
\hline May & 36 & & 328 & & 13 & & 14 & & $1 / 2$ & \\
\hline Jun & 44 & & 421 & & 11 & & 11 & & $1 / 1$ & \\
\hline Jul & 44 & & 444 & & 8 & & 8 & & 1/1 & \\
\hline Aug & 44 & & 462 & & 10 & & 10 & & $1 / 1$ & \\
\hline Sep & 43 & & 425 & & 9 & & 10 & & $1 / 2$ & \\
\hline Oct & 44 & & 426 & & 12 & & 13 & & $1 / 2$ & \\
\hline Nov & 46 & 10 & 448 & 263 & 17 & 2 & 18 & 2 & $1 / 2$ & $1 / 1$ \\
\hline Dec & 46 & 10 & 418 & 108 & 27 & 2 & 48 & 2 & $1 / 2$ & $1 / 1$ \\
\hline 2002 & & & & & & & & & & \\
\hline Jan & 45 & 10 & 442 & 271 & 65 & 11 & 111 & 12 & $1 / 11$ & $1 / 2$ \\
\hline Feb & 46 & 10 & 458 & 240 & 86 & 2 & 134 & 2 & $1 / 6$ & $1 / 1$ \\
\hline Mar & 46 & 10 & 582 & 305 & 91 & 5 & 134 & 5 & $1 / 5$ & $1 / 1$ \\
\hline Apr & 46 & 10 & 580 & 264 & 39 & 13 & 60 & 13 & $1 / 5$ & $1 / 1$ \\
\hline May & 46 & 10 & 515 & 261 & 69 & 7 & 85 & 7 & $1 / 3$ & $1 / 1$ \\
\hline Jun & 46 & 10 & 518 & 227 & 57 & 2 & 70 & 2 & $1 / 3$ & $1 / 1$ \\
\hline Jul & 46 & 10 & 523 & 274 & 40 & 5 & 53 & 5 & $1 / 3$ & $1 / 1$ \\
\hline Aug & 46 & 10 & 530 & 254 & 22 & 3 & 25 & 3 & $1 / 3$ & $1 / 1$ \\
\hline Sep & 46 & 5 & 531 & 126 & 16 & 0 & 19 & 0 & $1 / 2$ & - \\
\hline Oct & 22 & 5 & 245 & 120 & 2 & 0 & 2 & 0 & $1 / 1$ & - \\
\hline Nov & 46 & 10 & 511 & 239 & 3 & 0 & 3 & 0 & $1 / 1$ & - \\
\hline Dec & 46 & 10 & 244 & 228 & 8 & 2 & 17 & 2 & $1 / 2$ & $1 / 1$ \\
\hline 2003 & & & & & & & & & & \\
\hline Jan & 46 & 5 & 261 & 126 & 21 & 3 & 24 & 4 & $1 / 2$ & $1 / 2$ \\
\hline Totals & & & 12304 & 3306 & 944 & 57 & 944 & 59 & - & - \\
\hline
\end{tabular}

2003, when 1 host individual was observed with 2 parasites. No relationship was observed between infestation and host density. Host density did not vary during the study period, while parasite prevalence did (Fig. 4). $I_{\mathrm{ms}}$ was not computed for E. mathaei since the number of symbionts recorded on the host never exceeded 2.

\section{Population structure: recruitment, growth, density and mortality}

The temporal evolution of length-frequency distributions of 17 successive samples of Vexilla vexillum found on Tripneustes gratilla is illustrated in Fig. 5. Distribution analyses were performed only when the sample size was greater than 35. The number of identified subgroups, their characteristics and the statistical significance of the analyses are presented in Table 2.

During the 27 mo survey, 2 significant recruitment episodes were identified, January 2001 and December 2001 respectively. These periods were characterised by bimodal length-frequency distributions with significant numbers of gastropods $<0.5 \mathrm{~cm}$ in shell length. These small individuals were considered new Vexilla vexillum recruits. In January 2001, $75 \%$ of the population were new recruits with a mean $( \pm \mathrm{SE})$ shell length of $0.41 \pm 0.03 \mathrm{~cm}$, while in December 2001 they formed $87 \%$ of the population with a mean $( \pm \mathrm{SE})$ shell length of $0.40 \pm 0.03 \mathrm{~cm}$. In January 2003, a few small gastropods (shell length $<0.5 \mathrm{~cm}$ ) started to recruit but the sample size was too small to be analysed (Fig. 5). The population in 2001 was characterised by cohorts of older individuals and of new recruits; the latter were distinguishable from the older individuals during 3 mo after the first detection of recruitment. After April

Echinometra mathaei was infested to a much lesser degree than Tripneustes gratilla. Among 3306 individuals of E. mathaei sampled, only 57 (1.7\%) were infested by Vexilla vexillum (Table 1). Even though monthly $P$ values in $E$. mathaei never exceeded $5 \%$ (Fig. 4A), an annual cycle was discernible with a maximum of $4.9 \%$ in April 2003, and a gradual decrease to $0 \%$ by September 2002. No muricids were observed from September 2002 to November 2002. By December 2002, muricids had started to re-infest E. mathaei. The intensity of infestation (I) of E. mathaei (Table 1) was always 1, except on 2 occasions, in January 2002 and
2001 , length-frequency data were no longer significant due to the low number of sampled individuals, as indicated by the sample in May 2001 (Table 1). In December 2001, the proportion of individuals of $1 \mathrm{yr}$ of age (from recruitment in January of the same year) was only $13 \%$. Size-frequency data were more complete in 2002 due to the higher number of sampled gastropods. Distributions were also multimodal, except in March 2002. New recruit cohorts were distinguishable during the first 3 mo after recruitment (in December 2001). After March 2002 multimodality appeared again, probably due to successive mortality events. The popula- 

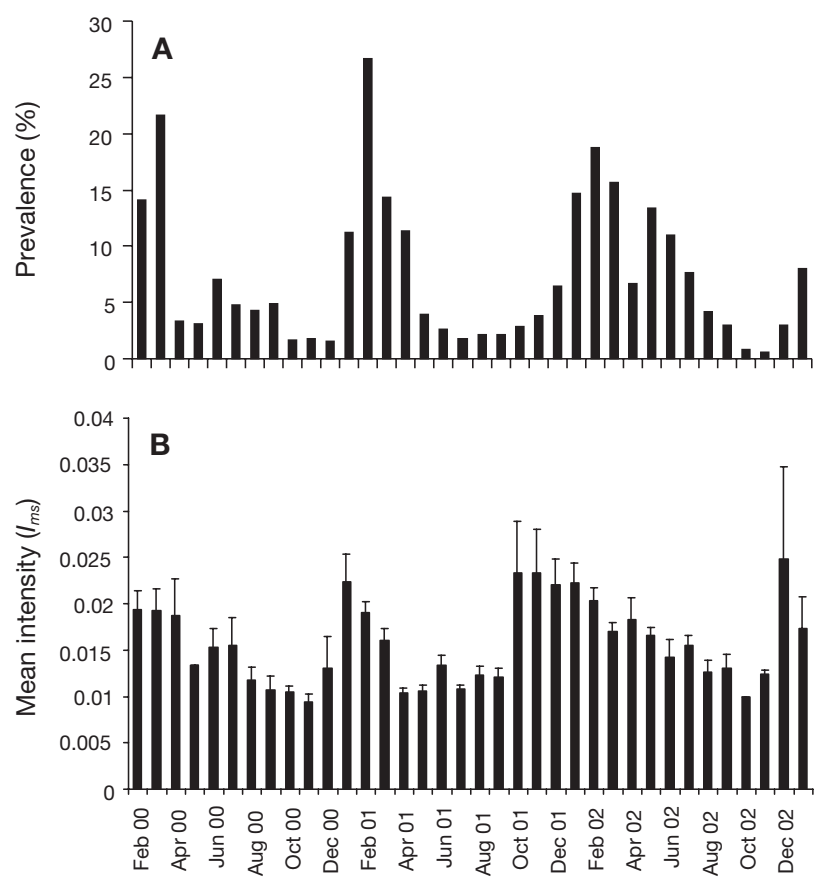

tion size was consequently greatly reduced by the end of the year.

The new recruit cohorts identified in the 2002 population (December 2001 to July 2002) and their displacement over time were used to study growth. Growth parameters were determined from Eq. (4) by plotting $L_{t}$

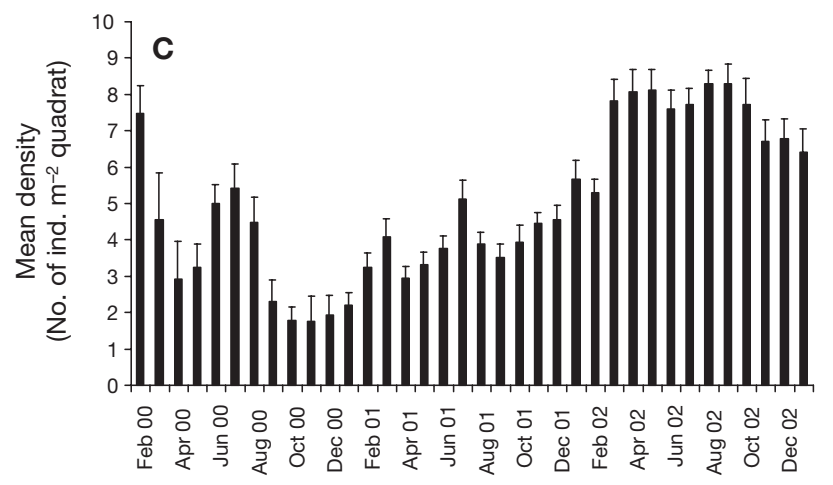

Fig. 3. Tripneustes gratilla. Changes in infestation and mean $(+\mathrm{SE})$ density during $3 \mathrm{yr}$ observation period. Infestation expressed as (A) prevalence and (B) mean (+SE) intensity. Density (C) expressed as number of individuals $\mathrm{m}^{-2}$ quadrat. See Table 1 for number of sampled individuals and quadrats

against $t$ using the mean shell length of new recruits determined after analysis by C.A.MAN and MIX programs (see Table 2). To fit the von Bertalanffy growth function, 2 assumptions were made: (1) Time at settlement ( $t=0$ ) was assumed to occur $25 \mathrm{~d}$ before the first new recruits were first observed, for the recruitment

Table 2. Vexilla vexillum. Length-frequency distribution results by C.A.MAN and MIX programs. Only monthly samples with $\mathrm{n}>35$ were used

\begin{tabular}{|c|c|c|c|c|c|c|c|c|c|}
\hline \multicolumn{2}{|c|}{ Date (dd.mm) } & \multirow{2}{*}{$\begin{array}{c}\mathrm{n} \\
39\end{array}$} & \multirow{2}{*}{$\begin{array}{c}\begin{array}{c}\text { No. of } \\
\text { subgroups }\end{array} \\
2\end{array}$} & \multirow{2}{*}{$\begin{array}{c}\begin{array}{c}\text { Means } \\
\text { (shell length) }\end{array} \\
0.406\end{array}$} & \multirow{2}{*}{$\begin{array}{c}\text { SE } \\
0.030\end{array}$} & \multirow{2}{*}{$\begin{array}{c}\begin{array}{c}\text { Weights } \\
\text { (g) }\end{array} \\
0.75\end{array}$} & \multicolumn{3}{|c|}{ Chi-square goodness-of-fit } \\
\hline \multirow[t]{10}{*}{2001} & 30.01 & & & & & & 12 & 4.039 & 0.983 \\
\hline & & & & 1.041 & 0.050 & 0.25 & & & \\
\hline & 27.02 & 203 & 2 & 0.573 & 0.012 & 0.61 & 7 & 6.644 & 0.467 \\
\hline & & & & 0.946 & 0.010 & 0.39 & & & \\
\hline & 28.03 & 52 & 2 & 0.910 & 0.021 & 0.63 & 10 & 11.506 & 0.320 \\
\hline & & & & 1.079 & 0.020 & 0.37 & & & \\
\hline & 17.04 & 66 & 2 & 0.900 & 0.020 & 0.86 & 8 & 5.308 & 0.724 \\
\hline & & & & 1.271 & 0.036 & 0.14 & & & \\
\hline & 30.12 & 48 & 2 & 0.400 & 0.025 & 0.87 & 15 & 26292 & 0.116 \\
\hline & & & & 1.507 & 0.020 & 0.13 & & & \\
\hline \multirow[t]{15}{*}{2002} & 30.01 & 111 & 2 & 0.689 & 0.017 & 0.58 & 8 & 6.46 & 0.596 \\
\hline & & & & 1.104 & 0.014 & 0.42 & & & \\
\hline & 26.02 & 134 & 2 & 0.767 & 0.018 & 0.82 & 12 & 16.723 & 0.169 \\
\hline & & & & 1.277 & 0.016 & 0.19 & & & \\
\hline & 27.03 & 134 & 1 & 0.918 & 0.028 & 1.00 & 14 & 15292 & 0.359 \\
\hline & 25.04 & 60 & 3 & 0.469 & 0.010 & 0.14 & 12 & 6.900 & 0.864 \\
\hline & & & & 0.847 & 0.018 & 0.41 & & & \\
\hline & & & & 1.360 & 0.030 & 0.45 & & & \\
\hline & 29.05 & 85 & 2 & 0.636 & 0.016 & 0.51 & 11 & 14233 & 0.218 \\
\hline & & & & 1.104 & 0.017 & 0.49 & & & \\
\hline & 27.06 & 70 & 3 & 0.401 & 0.012 & 0.05 & 13 & 19.421 & 0.111 \\
\hline & & & & 0.900 & 0.024 & 0.80 & & & \\
\hline & & & & 1.311 & 0.025 & 0.15 & & & \\
\hline & 25.07 & 53 & 2 & 0.619 & 0.012 & 0.25 & 6 & 9.170 & 0.164 \\
\hline & & & & 1.107 & 0.024 & 0.75 & & & \\
\hline
\end{tabular}



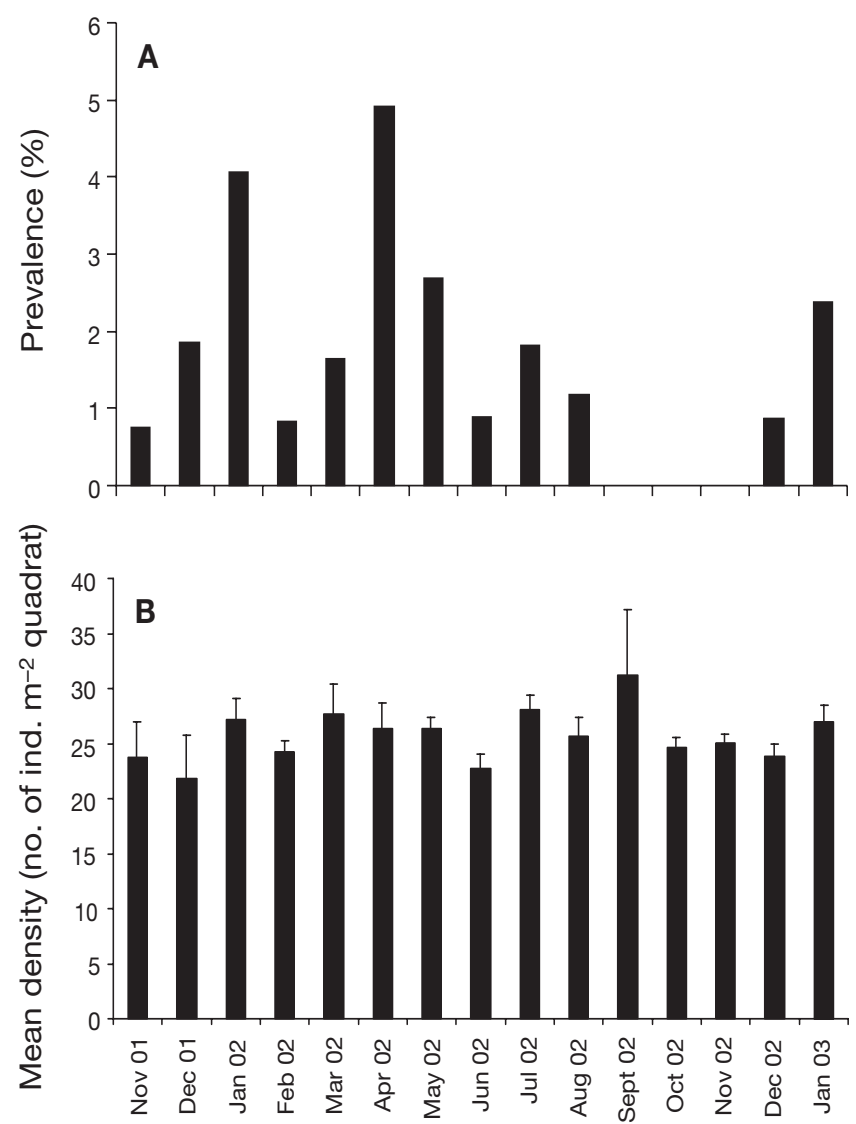

Fig. 4. Echinometra mathaei. Changes in infestation prevalence and mean (+SE) density over 15 mo observation period. See Table 1 for number of sampled individuals and quadrats

event on 30 December $2001 t=0$ was considered to be 5 December 2001; (2) when new recruits were no longer distinguishable from cohorts of older individuals (data after March 2002), the mean shell length, calculated from the whole distribution, was used to fit the growth function. Under these assumptions, the mean shell length $( \pm \mathrm{SE})$ of the 2002 population were plotted against time after settlement (putative age of gastropod individuals) in Fig. 6. The growth-curve fitting and parameter estimates were statistically significant $(F$ test, $\mathrm{p}<0.05)$. The von Bertalanffy growth function explained $97.5 \%\left(\mathrm{R}^{2}=0.975\right)$ of the total variation in the observed data. Estimated asymptotic shell length $\left(L_{\infty}\right)$ was $1.024 \pm 0.082 \mathrm{~cm}( \pm 95 \%$ confidence interval), scaling parameter $b$ was $0.943 \pm 0.113$ and growth rate constant $K$ was $0.019 \pm 0.003 \mathrm{~d}^{-1}\left(6.935 \pm 1.095 \mathrm{yr}^{-1}\right)$. Shell length at settlement $\left(L_{0}\right)$, calculated from Eq. (5), was $0.058 \mathrm{~cm}$. The curve predicts that $50 \%$ of the asymptotic size will be reached 1.5 mo after settlement and asymptotic shell length will be reached 5 mo later.

Fig. 7 illustrates the monthly abundance of Vexilla vexillum in terms of density $\left(D_{\text {; }}\right.$ number of individuals
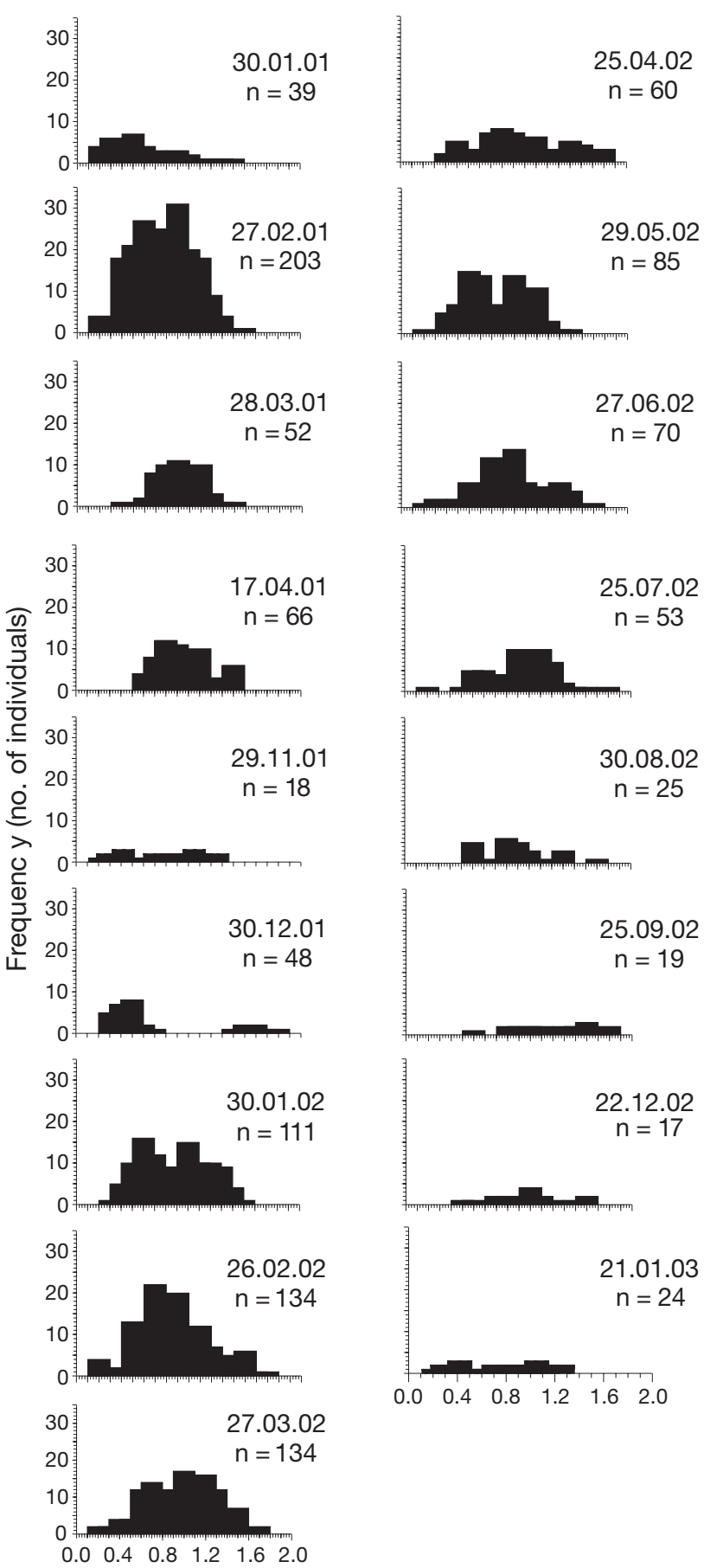

Shell length $(\mathrm{cm})$

Fig. 5. Vexilla vexillum. Length-frequency distributions of 17 samples collected from January 2001 to January 2003. Dates given as dd.mm.yy

per unit surface area of Tripneustes gratilla) throughout the study period. Annual variation in density was observed, with peaks in February to March corresponding to 1 or 2 mo after the first detection of new recruits in 2001 and 2002. A sudden drop in density 


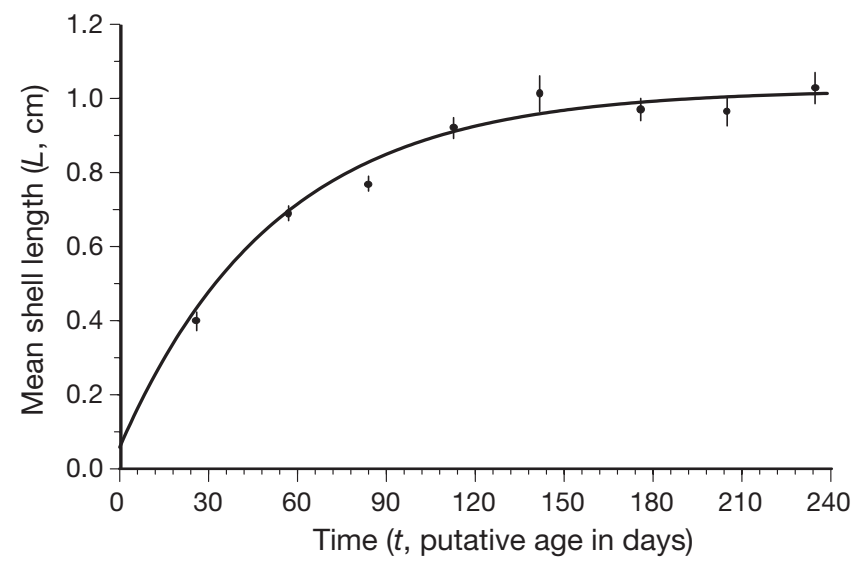

Fig. 6. Vexilla vexillum. Von Bertalanffy growth curve fitted to mean $( \pm \mathrm{SE})$ shell lengths obtained from analysis of the length-frequency distributions of population in 2002 (see also Table 2). Growth function was $L=1.024\left[1-0.943\left(\mathrm{e}^{-0.019 t}\right)\right]$ and fitting was significant (nonlinear regression: $F$-ratio $=1001$, $\mathrm{df}=3,5, \mathrm{p}<0.05$ )

was then observed, indicating high mortality events. In 2001, the number of $V$. vexillum in the population decreased by $97 \%$ in 5 mo (from February to July) while in 2002 a more gradual decrease was observed, resulting from $98 \%$ mortality after 8 mo.

A better estimation of mortality rate was obtained from the length-frequency data of the 2002 population using the Zkan programme. Time at recruitment ( $T=$ 0) was fixed as December 2001 since recruitment was optimum at this time as suggested by the lowest mean shell length recorded. The programme estimated $Z$ using values of the growth parameters determined earlier $\left(K=6.935 \mathrm{yr}^{-1}\right.$ and $\left.L_{\infty}=1.024 \mathrm{~cm}\right)$. Likewise, the $L_{\mathrm{R}}$ value used was $0.400 \mathrm{~cm}$, which corresponded to the mean shell length of recruits in December 2001 (Table 2). The shape parameter $s p$ was fixed to -1 since the von Bertalanffy function successfully described

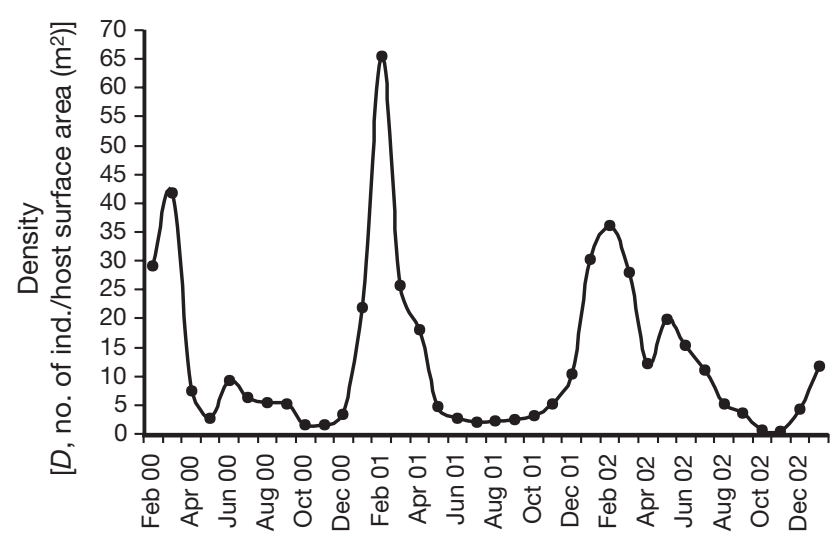

Fig. 7. Vexilla vexillum. Monthly variation in density during the $3 \mathrm{yr}$ observation. Density expressed as number of gastropods $\mathrm{m}^{-2}$ surface area of Tripneustes gratilla growth of Vexilla vexillum. Assumptions concerning $L_{\mathrm{R}}$ and $s p$ follow the conditions of by Ebert (1999) to run the programme. Using these known parameters, the $Z$ estimate was $0.796 \pm 0.038 \mathrm{yr}^{-1}( \pm \mathrm{SE})$ with an RSS of 0.010. Annual mortality rate $(q)$ calculated from Eq. (6) was $0.549 \mathrm{yr}^{-1}\left(54.9 \% \mathrm{yr}^{-1}\right)$ for the population in 2002.

\section{Size correlation between Vexilla vexillum and its echinoid hosts}

The relationship between Vexilla vexillum's shell length and the diameter of its echinoid hosts Tripneustes gratilla and Echinometra mathaei was investigated. Both host species showed poor correlations (T. gratilla; $\mathrm{r}=0.135, \mathrm{p}=0.14$, E. mathaei; $\mathrm{r}=0.302, \mathrm{p}=$ $0.30)$, indicating no linear association between shell length and diameter of the echinoid test. Conversely, when test diameters $(d)$ of $T$. gratilla were grouped into 3 classes - small $(d \leq 4 \mathrm{~cm})$, medium size $(4 \mathrm{~cm}<$ $d \leq 7 \mathrm{~cm})$, and larger $(d>7 \mathrm{~cm})$ individuals - and plotted against the corresponding number of gastropods, a significantly (Kruskal-Wallis test, p < 0.05) positive relationship was revealed, suggesting that smaller host individuals tend to have fewer parasites than larger ones (Fig. 8). The high variability in larger T. gratilla individuals is explained by the fact that they were infested with 1 to 11 gastropods, while smaller individuals often had only 1 or 2 gastropods. No such correlation could be computed for $E$. mathaei because of the low intensity of infestation.

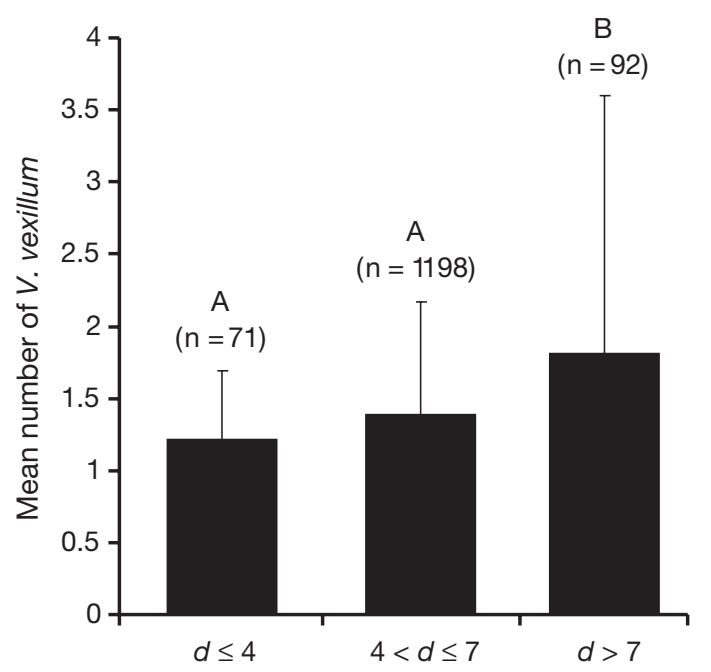

Fig. 8. Vexilla vexillum. Mean $(+\mathrm{SD})$ number observed on 3 size classes (diameter $d, \mathrm{~cm}$ ) of Tripneustes gratilla. Means calculated from pooled data from February 2000 to January 2003. Histograms bearing different letters differ significantly from each other (Kruskal-Wallis test, $\mathrm{p}<0.05$ ). Nos. in parentheses: total numbers of $T$. gratilla in relevant size class 

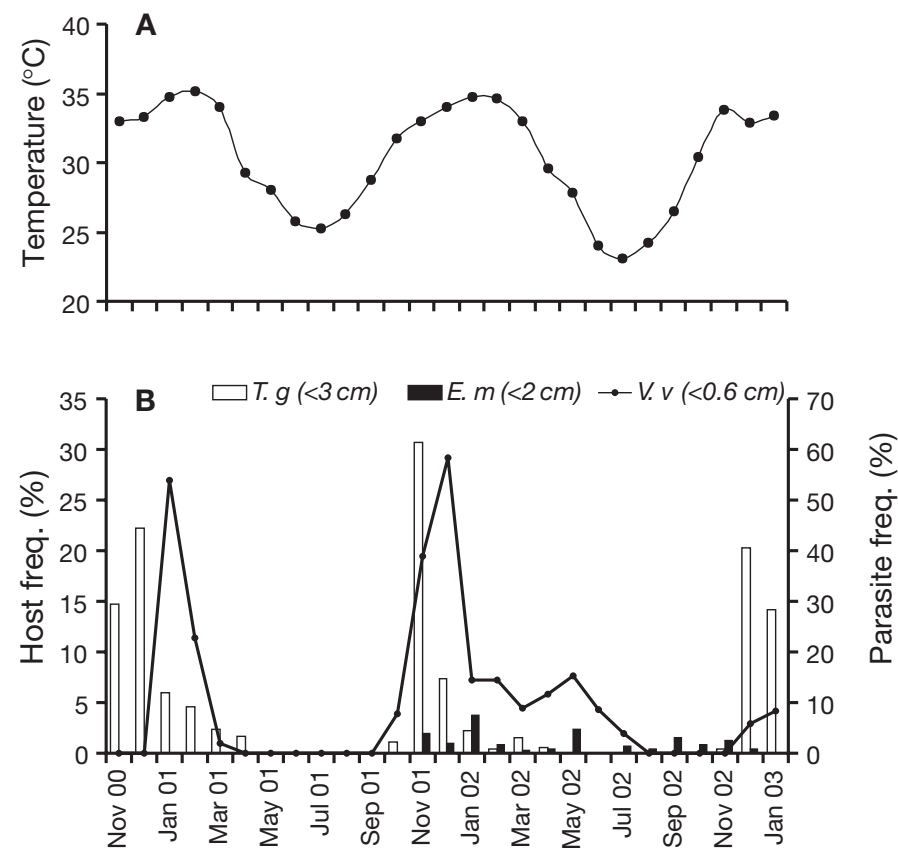

Fig. 9. (A) Monthly sea water temperature and (B) frequency $(\%)$ of small hosts and small gastropods during study period study with E. mathaei started from November 2001 only. T.g: Tripneustes gratilla; E.m: Echinometra mathaei; V.v: Vexilla vexillum

The monthly proportion of small hosts (test diameters $<3 \mathrm{~cm}$ ) to that of small gastropod individuals (shell length $<0.60 \mathrm{~cm}$ ), together with the corresponding sea water temperature are illustrated in Fig. 9. Surveys in November 2001 showed that the proportion of small Echinometra mathaei individuals rarely exceeded $3 \%$, indicating no peak period of recruitment. In contrast, like Vexilla vexillum, recruitment of Tripneustes gratilla seemed to be periodic and small individuals were detected from November to April of each year, with peaks in November to December indicating new recruits. Peaks of new recruits of $V$. vexillum were observed 1 mo after small individuals of T. gratilla were observed. Recruitment peaks of both T. gratilla and $V$. vexillum coincided with increasing sea water temperature (Fig. 9). The close relationship between the recruitment events of $T$. gratilla and $V$. vexillum suggest that small-sized hosts harbour small-sized parasites. However, the proportion of small T. gratilla individuals infested with small gastropod individuals (shell length $<0.60 \mathrm{~cm}$ ) was $<2 \%$.

\section{Location and effects of Vexilla vexillum on its echinoid hosts}

Vexilla vexillum (Fig. 10A) was always found in association with echinoids and no free-living individu- als were recorded. The gastropods were observed moving freely on the echinoid test while grazing over the host integument. Although surveys were done at low tides, complementary observations were made during high tides by SCUBA diving which revealed similar patterns of association. For both host species, the gastropod was usually located on the oral region of the test, particularly on the peristomeal membrane when not actively feeding. When feeding, traces of grazed test were always found on the oral region of Echinometra mathaei while oral and aboral regions of Tripneustes gratilla were equally grazed. The feeding process was followed in the laboratory. Upon contact with the test (Fig. 10B), the gastropod was first observed to secrete a mucus substance. Then, the radula located at the top of $V$. vexillum's proboscis was used to graze the echinoid integument. Fig. 10C is a scanning electron microscope photograph of the radula showing 1 row of broad and robust central (rachidian) teeth and 2 rows of curved, serrated lateral teeth.

Infestation experiments on Tripneustes gratilla showed that 9 out of the 20 individuals tested were infested after $14 \mathrm{~d}$. On Day 2 there were 5 infestations, on Day 4 there were 2, on Day 10 there was 1, and on Day 14 there was also 1 . Of the 9 infested echinoids, 6 had lesions on the bare zones while the other 3 had lesions on the spiny zones. Depending on their size, lesions were either resorbed or increased in size. Fig. 10D shows a small lesion (about $0.60 \mathrm{~cm}^{2}$ ) $2 \mathrm{~d}$ after infestation; 14 d later, an SEM of the same lesion revealed partial regeneration of the epidermal tissue; regenerating spines and other appendages were visible together with an epidermal strip surrounding a test area that was still recovering (Fig. 10E). For larger lesions $\sim 1.30 \mathrm{~cm}^{2}$ (Fig. 10F), however, epidermal regeneration did not occur, and infected areas turned black (Fig. 10G), probably through secondary infection by micro-organisms. Fig. $10 \mathrm{H}$ shows the large lesion in Fig. 10G 35 d later; the lesion has increased in size and a perforation is visible in the test, which resulted in the host's death.

\section{Mechanism and specificity of host recognition}

The response of Vexilla vexillum to a chemical stimulus was demonstrated by olfactory experiments (Table 3). When placed at the base of the Y-tube, siphonal probing behaviour was adopted by every stimulated individual. This consisted of extension and elevation of the siphon towards the chemical stimulus in the water flow; the stimulated individual then moved towards the chemical stimulus. Comparison of the results of Olfactory Test 1 (control test, Table 3) 

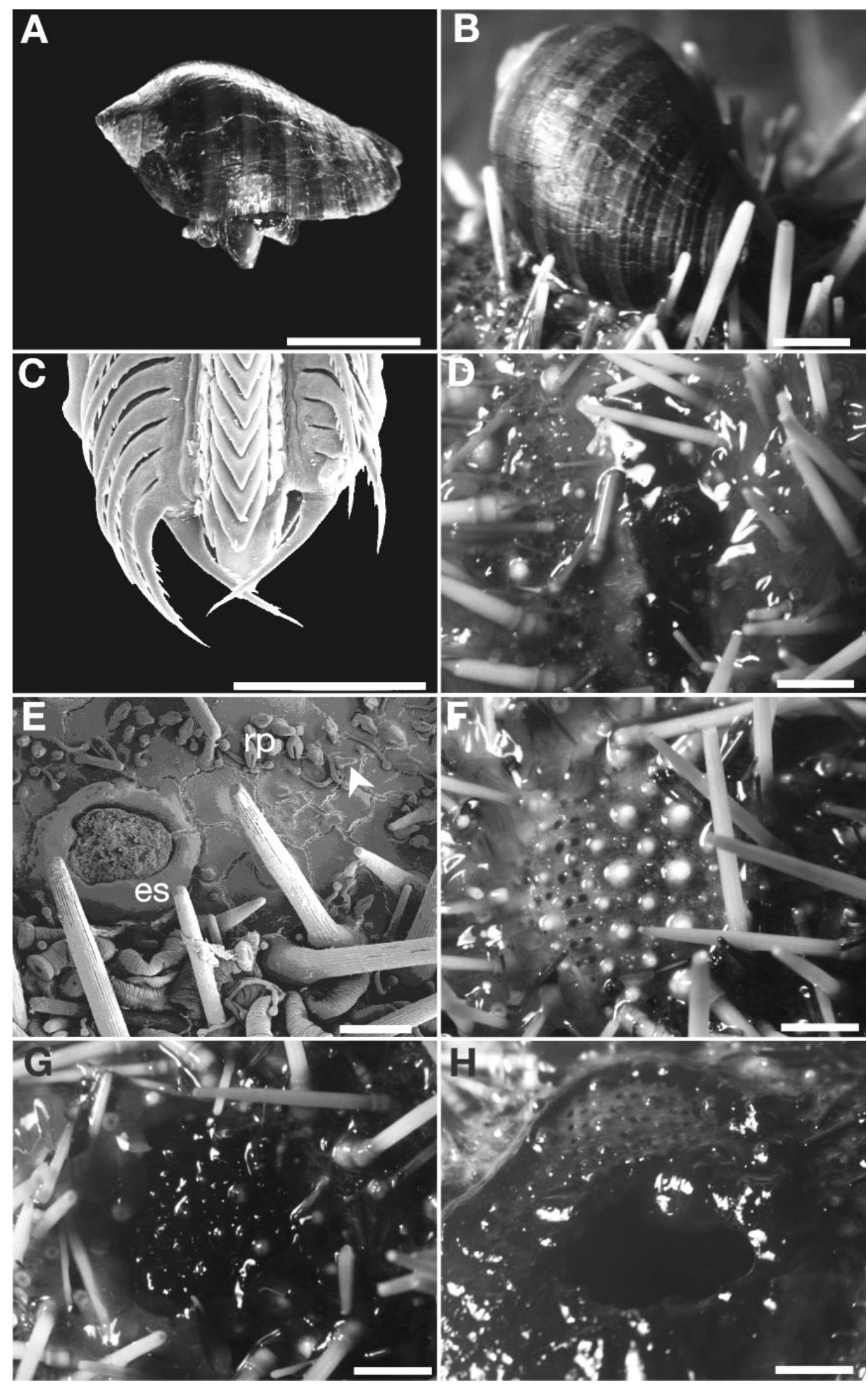

Fig. 10. Vexilla vexillum. (A) Side view (light microscopy, LM) of adult (scale bar $=0.5 \mathrm{~cm}$ ). (B) In situ observation of adult on host Tripneustes gratilla $(\mathrm{LM}$; scale bar $=0.25 \mathrm{~cm})$. (C) SEM of radula (scale bar $=100 \mu \mathrm{m})$. (D-H) Test lesions on host T. gratilla: (D) LM of $2 \mathrm{~d}$-old $0.6 \mathrm{~cm}^{2}$ test lesion (scale bar $=0.5 \mathrm{~cm}$ ); (E) SEM of same lesion as in (D) $14 \mathrm{~d}$ later (scale bar $\left.=1 \mathrm{~mm}\right)(\mathrm{es}$ : epidermal strip; rp: regenerating pedicellaria; arrowhead: regenerating spine). (F,G,H) Large, $1.3 \mathrm{~cm}^{2}$ test lesion $2 \mathrm{~d}(\mathrm{~F}), 14 \mathrm{~d}(\mathrm{G})$ and $35 \mathrm{~d}(\mathrm{H})$ after grazing, note that in this particular lesion, epidermal regeneration did not occur, and led to test perforation (H) (all scale bars $=0.5 \mathrm{~cm})$ 
Table 3. Vexilla vexillum. Olfactory tests evidencing chemical attraction of $V$. vexillum by echinoids using a Davenport's Y-tube system. FSW: filtered sea water. Results of test 1 (control experiment) was compared to a theoretical one (ratio $50 \%: 50 \%$ ), and no significant difference were observed (chi-square test, $\mathrm{p}>0.05$ ). All other comparisons were done between observed and test 1 results again using chi-square test: 1, comparison between the number of moving muricids $(\mathrm{A}+\mathrm{B})$ when they were stimulated by the odour of an echinoid to the number of non stimulated ones (void) and 2, comparison of choices between Aquarium A or B

\begin{tabular}{|c|c|c|c|c|c|c|c|c|c|}
\hline \multirow{2}{*}{ Test } & \multirow{2}{*}{$\begin{array}{l}\text { Time }(\mathrm{s}) \\
\min / \max \end{array}$} & \multirow{2}{*}{\multicolumn{2}{|c|}{$\begin{array}{r}\text { Aquarium } \\
\mathrm{A}\end{array}$}} & \multicolumn{4}{|c|}{ Results } & \multicolumn{2}{|c|}{ Chi-square (p) } \\
\hline & & & & Assay & Void & $\mathrm{A}$ & B & 1 & 2 \\
\hline 1 & $85 / 664$ & FSW & FSW & 30 & 13 & 10 & 7 & - & - \\
\hline 2 & $15 / 531$ & Tripneustes gratilla & FSW & 30 & 4 & 24 & 2 & $<0.001$ & $<0.001$ \\
\hline 3 & $52 / 779$ & FSW & Echinometra mathaei & 30 & 10 & 4 & 16 & 0.269 & 0.027 \\
\hline 4 & $95 / 841$ & Stomopneustes variolaris & FSW & 30 & 17 & 9 & 4 & 0.111 & 0.239 \\
\hline 5 & $56 / 472$ & Echinometra mathaei & Tripneustes gratilla & 30 & 2 & 5 & 23 & $<0.001$ & $<0.001$ \\
\hline
\end{tabular}

with a theoretical result $(50 \%: 50 \%)$ using a chisquare test revealed no response of the muricid individuals in the absence of chemical stimulus. Thus, when gastropods were presented with 2 aquaria filled with filtered sea water, there was no significant difference between the number of non-stimulated individuals (void test) and the number of individuals which were stimulated and moved to either A or B (chi-square test, $\mathrm{p}=0.465$ ). Furthermore, among the 17 muricids which did move, no significant difference was found in the choice between Aquaria A or B (chisquare test, $\mathrm{p}=0.467$ ). However, when Tripneustes gratilla was placed in one of the aquaria (Test 2, Table 3), the gastropod responded significantly (chisquare test, $\mathrm{p}<0.001$ ) towards the stimulus, indicating a positive response towards an odour released by the host.

The odour which triggers gastropod attraction seemed to be specific to host species. Stomopneustes variolaris, which is not a natural host, did not significantly (Test 4 , chi-square test, $\mathrm{p}=0.111$ ) stimulate a response in the gastropods. Even among those which did move, there was no significant difference between A or B (chi-square test, $p=0.239$ ). Since the results of Test 4 were not statistically different from control results (Test 1), no further tests between $S$. variolaris and host species were made. A clear preference for Tripneustes gratilla was observed when the muricid was confronted with a choice between the 2 potential hosts (Test 5 ), with a highly significant (chi-square test, $\mathrm{p}<0.001$ ) response to T. gratilla. The results of Tests 2 and 3 confirmed this preference. When faced with a choice between T. gratilla and FSW, $80 \%$ of the gastropods responded, while with a choice of E. mathaei or FSW, a response of only $53 \%$ was recorded. The response time results confirmed these above observations: the shortest response time was recorded when the muricid was exposed to its host $T$. gratilla (Test 2), the longest time when exposed to a non-host echinoid (Test 4).

\section{DISCUSSION}

This study has demonstrated the occurrence of a parasitic association between Vexilla vexillum and 2 echinoid hosts, Tripneustes gratilla and Echinometra mathaei, on the barrier reef off Toliara. Periodical fluctuations in the prevalence of the muricid were observed, closely linked to the dynamics of its population structure. Indeed, intense annual recruitment episodes with a high growth rate of new recruits and a very low survivorship of older muricid individuals were recorded. Furthermore, both field surveys and laboratory experiments revealed a clear preference of the muricid for its host species T. gratilla.

This preferential infestation of Tripneustes gratilla could be attributed to certain physical characteristics of its test morphology. Individuals of T. gratilla, a member of the family Toxopneustidae, are characterised by large test diameters and relatively short primary spines (not uniformly distributed: bare zones alternate with spiny zones) while individuals of the other echinoid host, the echinometrid Echinometra mathaei, have smaller tests with longer uniformly distributed spines. The test morphology of $T$. gratilla probably provides a greater surface area together with better accessibility for grazing by the muricids on the bare zones. Additionally, olfactory experiments revealed that snails were highly attracted by the odour of $T$. gratilla. These observations together with the siphonal probing behaviour developed by every stimulated individual of Vexilla vexillum, clearly indicate that a host-recognition mechanism exists and that water-borne chemical cues probably play an important role in such mechanism. Such behaviour is typical of most non-herbivorous prosobranchs, who have developed a siphonal canal which directs the inhalant water current onto a highly developed organ, the osphradium, used for detecting odours (Purchon 1968, Hughes 1986). The use of chemotaxis in host recognition has been reported in various other symbiotic associations (VandenSpiegel et 
al. 1998, Hamel et al. 1999, Eeckhaut et al. 2001). Our results suggest the occurrence of such recognition mechanism in $V$. vexillum and demonstrate the high ability of the muricid to discriminate T. gratilla from other sympatric echinoid species, therefore inferring the existence of certain host-specificity. Both test morphology and host-recognition capacity and specificity could explain the higher rate of infestation on $T$. gratilla compared to of E. mathaei.

The population structure of Vexilla vexillum clearly indicates pulsed recruitment events that occurr annually from December to January. This annual pattern would seem to indicate a seasonal event determined by a seasonally synchronised reproductive cycle of the gastropod. Gastropod reproduction is generally influenced by reproductive hormones whose levels are controlled by exogenous and endogenous factors such as temperature, photoperiod and nutritional state (Underwood 1974, Hughes 1986). In some regions of Toliara, temperature varies between austral winter (cool, dry season from April to September) and austral summer (warm, humid season from October to March). The mean $( \pm \mathrm{SD})$ sea water temperature recorded in summer was $32.4 \pm 2.3^{\circ} \mathrm{C}$ while in winter it was $25.6 \pm$ $1.7^{\circ} \mathrm{C}$. Although the reproduction of $V$. vexillum has not been studied, temperature probably plays a predominant role in determining its reproductive cycle. The recruitment of $V$. vexillum during December to January (middle of the warm season) and laboratory observations of the duration of its larval development (40 d from laying to metamorphosis: D. Vaïtilingon unpubl. data) indicate a laying period from October to November, during the transition between the cool and warm seasons, corresponding to a rise in the mean sea water temperature. Hence, a temperature-dependent laying period could explain the pulsed recruitment.

Most host-parasite relationships have coevolved and complex life-history patterns (Stiling 1999) and very often, the parasite life cycle is influenced by its host biology and ecology. Although investigations on parasite-echinoderm host ecology are rare, a few studies have revealed a close relationship of the life cycle of the parasite with that of its host. Lützen (1979) showed that entoconchid (gastropods) parasites were dependent on the annual evisceration of the aspidochirote holothurian hosts to complete their life cycle. Byrne (1985) showed that the establishment of the endoparasitic gastropod Thyonicola americana is dependent on the population density of its holothuroid host, and that annual evisceration of the host may prevent the parasite from completing its life cycle. The life cycle of Vexilla vexillum may also be related to its host's life cycle. Tripneustes gratilla has been described as an annual, short-lived species (Ebert 1982, Lawrence \& Bazhin 1998). One of the characteristic features of a short-lived species is the predictability of their recruitment (Ebert 1975), and our observations confirmed annual recruitment in $T$. gratilla. This, together with its high annual recruitment rate (>20\% of new recruits each year) could favour its association with $V$. vexillum in 2 ways. (1) An increase in the density of $T$. gratilla through a sudden recruitment event will increase the probability of a newly metamorphosed muricid individual encountering a host, not only through an increase in the surface area available for settlement, but also by increasing the intensity of the host's chemical cue. The ability of most invertebrate larvae to locate appropriate habitats for settlement, metamorphosis and growth by responding to chemical cues associated with conspecific individuals, food sources and other benthic substrata is well known (Crisp 1974, Burke 1983, Hadfield 1978, 1998). (2) T. gratilla may provide a stable and predictable nutritional environment that allows better establishment, rapid growth and completion of $V$. vexillum's life cycle in a very short time. This hypothesis is consistent with the conclusions of Heller (1990) in a review of gastropod longevity which revealed that short-lived species are often associated with a predictable environment and high temperature (characteristic of tropical waters). Host-predictability has been proposed as one of the conditions favouring host-specificity (Warén 1983). Observations of Echinometra mathaei's population structure showed that recruitment was less predictable than in T. gratilla, and this may also explain the muricid's specificity for the latter species.

Host-infestation dynamics are directly linked to gastropod population dynamics. Given that gastropods are always found on their host, any increase in parasite density after a recruitment event would lead to increased infestation. Thus, the close relationship between infestation and recruitment also suggests infestation is seasonal, with peaks in the middle of the warm season, shortly after each recruitment. Seasonal variation in infestation has been observed in eulimidechinoderm associations (Morton 1979, Crossland et al. 1991). However, in such associations, seasonal variability is not due to juvenile recruitment but to variability in nutrient supply. The seasonality in infestation of Vexilla vexillum was also due to the observed exponential decrease in its density. This decrease is marked, and probably reflects the reproductive behaviour of $V$. vexillum. Like most prosobranchs, muricids are gonochoristic (Hughes 1986). After mating, the females generally enclose batches of eggs in capsules which they fix onto the substratum (Hughes 1986, Bramachary 1989). Throughout the $3 \mathrm{yr}$ of our survey, no egg capsules were found fixed on individuals of either host species. However, laboratory observations showed that $V$. vexillum do produce such egg capsules and fix 
them on the substratum (D. Vaïtilingon unpubl. data). The rapid growth rate of the parasite may indicates that it reaches sexual maturity in a relatively short period after settlement. Consequently, it is highly probable that soon after sexual maturity, copulation occurs and female $V$. vexillum leave their hosts to fix their eggs capsules under rocks, and then die, as do the males after copulation. Death may be either natural, since the species is short-lived, or due to higher predatory pressures, a direct consequence of leaving their host [see Warèn (1983) for a description of parasite adaptations to predation]. Furthermore, all these characteristics support the idea that $V$. vexillum is a semelparous species, with a high growth rate, low survivorship and high reproductive effort (intense recruitment), which dies after a single reproductive event (Hughes 1986).

The feeding mechanism of Vexilla vexillum greatly resembles the mode of food acquisition of most predatory neogastropods. However, V. vexillum cannot be considered as a predator (micro-predator) since a predator has a direct lethal effect on its prey (Sih 1987), and this study has demonstrated that grazing of $V$. vexillum does not directly kill its host. Host death appears to be due to secondary infection of grazed zones by micro-organisms. The progression of the lesions on Tripneustes gratilla after grazing by the muricid was very similar to that observed for sea urchins suffering from bald sea-urchin disease, whose causative agent is of bacterial nature (Maes \& Jangoux 1985, Jangoux 1990, Bauer \& Young 2000). In the present study, although the echinoid host seemed to tolerate the parasite association, secondary infection by microorganisms may have important ecological and commercial impacts due to a sudden reduction in echinoid population size. The ultimate consequences of echinoid diseases caused by micro-organisms are known to be a reduction in the echinoid population (Jangoux 1990). During our field survey, we observed individuals with lesions similar to those observed under experimental conditions, confirming that epidermal grazing has the same effect under natural conditions. This study has shown a close relationship between $V$. vexillum and its host T. gratilla and provided evidence that $V$. vexillum is an ectoparasitic gastropod.

Acknowledgements. This work was supported by funds from the FRFC (Fond de la Recherche Fondamental Collective, grant no. 2.4574.01) and from the CUD (Coopération Universitaire au Développement) of the French Community of Belgium in the framework of the Tropical Echinoculture Programme in Madagascar. We wish to thank Dr. B. Métivier (Muséum National d'Histoire Naturelle, Paris) who helped to identify the gastropod species. We gratefully acknowledge the help of J. M. Ouin, R. Rasolofonirina, J. Ralainirina, P. Manohitsara, N. Fohy for technical and field assistance, and of Mr. Prosper, our Sailor. Thanks to Pierre Decker for preparing samples for SEM, to R. Morgan and 3 anonymous reviewers for criticising the manuscript. This paper is a contribution of the 'Centre Interuniversitaire de Biologie Marine' (CIBIM).

\section{LITERATURE CITED}

Barel CD, Kramers PG (1977) A survey of the echinoderms associates of the north-east Atlantic area. Zool Verh 156: 1-159

Bauer JC, Young CM (2000) Epidermal lesions and mortality caused by vibriosis in deep-sea Bahamian echinoids: a laboratory study. Dis Aquat Org 39:193-199

Böhning D, Schlattmann P, Lindsay B (1992) Computerassisted analysis of mixtures (C.A.MAN): statistical algorithms. Biometrics 48:283-303

Bramachary RL (1989) Mollusca. In: Adiyodi KG, Adiyodi RG (eds) Reproductive biology of invertebrates. Vol IV. Part A, fertilization, development and parental care. WileyInterscience, New York, p 281-348

Burke RD (1983) The induction of metamorphosis of marine invertebrate larvae: stimulus and response. Can J Zool 61: 1701-1719

Bush AO, Lafferty KD, Lotz JM, Shostak AW (1997) Parasitology meets ecology on its own terms: Margolis et al. revisited. J Parasitol 83:575-583

Byrne M (1985) The life history of the gastropod Thyonicola americana Tikasingh, endoparasitic in a seasonally eviscerating holothurian host. Ophelia 24:91-101

Crisp DJ (1974) Factors influencing the settlement of marine invertebrate larvae. In: Grant PT, Mackie AM (eds) Chemoreception in marine organisms. Academic Press, New York, p $177-265$

Crossland MR, Alford RA, Collins JD (1991) Population dynamics of an ectoparasitic gastropod, Hypermastus sp. (Eulimidae), on the sand dollar, Arachnoides placenta (Echinoidea). Aust J Mar Freshw Res 42:69-76

Davenport D (1950) Studies in the physiology of commensalism. 1 The polynoid genus Arctonoe. Biol Bull (Woods Hole) 98:81-93

Draper NR, Smith H (1998) Applied regression analysis, 3rd edn. Wiley-Interscience, New York

Ebert TA (1973) Estimating growth and mortality rates from size data. Oecologia 11:281-298

Ebert TA (1975) Growth and mortality in postlarval echinoids. Am Zool 15:755-775

Ebert TA (1982) Longevity, life history, and relative body wall size in sea urchins. Ecol Monogr 52:353-394

Ebert TA (1999) Plant and animal populations: methods in demography. Academic Press, San Diego

Eeckhaut I, VandenSpiegel D, Michel A, Jangoux M (2001) Host chemodetection by the crinoid associate Harrovia longipes (Crustacea: Brachyura: Eumedonidae) and a physical characterization of a crinoid-released attractant. Asian Mar Biol 17:111-123

Ellers O (1993) A mechanical model of growth in regular sea urchins: predictions of shape and a developmental morphospace. Proc R Soc Lond Ser B 254:123-129

Ellers O, Telford M (1992) Causes and consequences of fluctuating coelomic pressure in sea urchins. Biol Bull (Woods Hole) 182:424-434

Fujioka Y (1985) Population ecological aspects of the eulimid gastropod Vitreobalcis temnopleuricola. Malacologia 26: 153-163

Grosjean P, Spirlet C, Gosselin P, Vaïtilingon D, Jangoux M (1998) Land-based closed cycle echiniculture of Paracen- 
trotus lividus Lamarck (Echinoidea: Echinodermata): a long term experiment at a pilot scale. J Shellfish Res 17: 1523-1531

Hadfield MG (1978) Metamorphosis in marine molluscan larvae: an analysis of stimulus and response. In: Chia FS, Rice ME (eds) Settlement and metamorphosis of marine invertebrate larvae. Elsevier, New York, p 165-175

Hadfield MG (1998) Research on settlement and metamorphosis of marine invertebrate larvae: past, present and future. Biofouling 12:9-29

Hamel JF, Ng PKL, Mercier A (1999) Life cycle of the pea crab Pinnotheres halingi sp. nov., an obligate symbiont of the sea cucumber Holothuria scabra Jaeger. Ophelia 50: $149-175$

Heller J (1990) Longevity in molluscs. Malacologia 31: 259-295

Hughes RN (1986) A functional biology of marine gastropods. Croom Helm, London

Jangoux M (1990) Diseases of Echinodermata. In: Kinne O (ed) Diseases of marine animals, Vol III. Biologische Anstalt Helgoland, Hamburg, p 439-542

Jangoux M, Rasolofonirina R, Vaïtilingon D, Ouin JM, Seghers G, Mara E, Conand C (2001) A sea cucumber hatchery and mariculture project in Tulear, Madagascar. SPC Bêche-demer Inf Vall 14:2-5

Kay EA (1979) Hawaiian marine shells. Reef and shore fauna of Hawaii. Section 4: Mollusca. Bernice P Bishop Mus Spec Publ 64:251-252

Lawrence JM (1975) On the relationship between marine plants and sea urchins. Oceanogr Mar Biol Annu Rev 13: 213-286

Lawrence JM, Agatsuma Y (2001) The ecology of Tripneustes. In: Lawrence JM (ed) Edible sea urchins: biology and ecology. Elsevier, Amsterdam, p 395-413

Lawrence JM, Bazhin A (1998) Life-history strategies and the potential of sea urchins for aquaculture. J Shellfish Res 17: $1515-1522$

Lützen J (1972) Studies on parasitic gastropods from echinoderms. II. On Stilifer sp. Broderip, with special reference to the structure of the sexual apparatus and the reproduction. Biol Skr 19:1-18

Lützen J (1976) On a new genus and two new species of Prosobranchia (Mollusca), parasitic on the tropical sea urchin Echinometra mathaei. Isr J Zool 25:38-51

Lützen J (1979) Studies on the life history of Enteroxenos Bonnevie, a gastropod endoparasitic in aspidochirote holothurians. Ophelia 18:1-51

Macdonald PDM, Pitcher TJ (1979) Age-groups from sizefrequency data: a versatile and efficient method of analyzing distribution mixtures. J Fish Res Board Can 36: 987-1001

Maes P, Jangoux M (1985) The bald-sea-urchin disease: a

Editorial responsibility: Albert Sparks,

Seattle, Washington, USA bacterial infection. In: Keegan BF, O'Connor BD (eds) Proc Int Echinoderm Conf. Balkema, Rotterdam, p 313-314

McClanahan TR, Muthiga NA (2001) The ecology of Echinometra. In: Lawrence JM (ed) Edible sea urchin: biology and ecology. Elsevier, Amsterdam, p 225-243

Mortensen T (1943) A monograph of the Echinoidea, Vol III.2, Part 1, Camarodonta. CA Reitzel, Copenhagen

Morton B (1979) The population dynamics and expression of sexuality in Balcis shaplandi and Mucronalia fulvescens (Mollusca: Gastropoda: Aglossa) parasitic upon Archaster typicus (Echinodermata: Asteroidea). Malacologia 18: $327-346$

Ponder WF, Gooding RU (1978) Four new eulimid gastropods associated with shallow-water diadematid echinoids in the Western Pacific. Pac Sci 32:157-181

Purchon RD (1968) The biology of mollusca. Pergamon Press, Oxford

Régis MB, Thomassin BA (1982) Ecologie des échinoides réguliers dans les récifs coralliens de la région de Tuléar (S.O. de Madagascar): adaptation de la microstructure des piquants. Ann Inst Océanogr 58:117-158

Siegel S, Castellan NJ (1988) Non parametric statistics for the behavioral sciences, 2nd edn. McGraw-Hill, Singapore

Sih A (1987) Predators and prey lifestyles: an evolutionary and ecological overview. In: Kerfoot WC, Sih A (eds) Predation: direct and indirect impacts on aquatic communities. University Press of New England, Hanover, p 203-224

Stiling P (1999) Ecology, theories and application, 3rd edn. Prentice-Hall, Upper Saddle River, NJ

Underwood AJ (1974) The reproductive cycles and geographical distribution of some common eastern Australian prosobranchs (Mollusca: Gastropoda). Aust J Mar Freshw Res 25:63-88

UNEP/IUCN (United Nations Environment Programme/ International Union for conservation of Nature and Natural Resources) (1988) Madagascar. In: Coral reefs of the world. Vol 2: Indian Ocean, Red Sea and Gulf. UNEP Regional Seas Directories and Bibliographies, IUCN, Gland

VandenSpiegel D, Eeckhaut I, Jangoux M (1998) Host selection by Synalpheus stimpsoni (De Man), an ectosymbiotic shrimp of comatulid crinoids, inferred by a field survey and laboratory experiments. J Exp Mar Biol Ecol 225: 185-196

Vaught KC (1989) A classification of living Mollusca. American Malacologists, Melbourne, FL

Warén A (1980) Revision of the genus Thyca, Stylifer, Scalenostoma, Mucronalia and Echineulima (Mollusca, Prosobranchia, Eulimidae). Zool Scr 9:187-210

Warén A (1983) A generic revision of the family Eulimidae (Gastropoda, Prosobranchia). J Molluscan Stud 13:1-96

Zar JH (1996) Biostatistical analysis, 3rd edn. Prentice-Hall, Upper Saddle River, NJ

Submitted: December 3, 2003; Accepted: April 16, 2004

Proofs received from author(s): October 10, 2004 